\title{
Meningkatkan Kepuasan Nasabah Melalui Kualitas Pelayanan yang di Mediasi oleh Kepercayaan (Survey Pada BRI Kcp Unit Kuamang Kuning Kabupaten Bungo)
}

\author{
Andri Yandi \\ Dosen Fakultas Ekonomi Universitas Batanghari Jambi
}

\begin{abstract}
This study aims to analyze the effect of service quality on customer trust and satisfaction, trust in customer satisfaction, and analyze the influence of service quality through trust as a variable intervening on customer satisfaction. the sample is 384. The method of collecting data uses a survey method, which is followed by a statistical method to test the hypothesis that is by path analysis. The results of this study indicate that service quality has a positive and significant effect on customer trust and satisfaction, as well as trust has a positive and significant influence on customer satisfaction. In addition, service quality through trust also has an influence on customer satisfaction.
\end{abstract}

Keywords: Service Quality, Trust, and Satisfaction.

\section{PENDAHULUAN}

Perkembangan dunia perbankan dewasa ini semakin berkembang di Indonesia.Hal ini ditandai dengan banyaknya berdiri bank-bank swasta, baik lokal maupun penanam modal asing. Tidak hanya pada kota-kota besar saja, melainkan juga sudah merambah kewilayah kecamatan yang jauh dari pusat kota. Seperti halnya di Kuamang Kuning yang merupakan salah satu Kecamatan yang ada di Kabupaten Bungo. Dimana BRI telah membuka kantor cabang pembantu (KCP) unitnya selama kurang lebih dua puluh dua tahun belakang ini, dalam rangka mengambil peran di daerah pedesaan, dimana targetnya adalah masyarakat desa. Bisnis perbankan pada dasarnya berdasarkan pada prinsip kepercayaan. Faktor kepercayaan masyarakat merupakan suatu faktor yang amat penting, karena tanpa kepercayaan maka masyarakat tidak akan menabung dananya di bank, untuk itu bank harus mampu menjaga kepercayaan masyarakat tersebut.

Faktor kepercayaan merupakan faktor penting, karena tanpa kepercayaan maka masyarakat tidak akan menyimpan dananya di bank. Untuk itu bank harus mampu menjaga kepercayaan dari masyarakat bahwa dana yang disimpan aman. Menurut Jasfar (2000) menjelaskan bahwa kepercayaan merupakan refleksi dari dua komponen, yaitu Credibility dan Benevolence.Credibility didasarkan pada besarnya kepercayaan kemitraan dengan organisasi lain dan membutuhkan keahlian untuk menghasilkan efektifitas dan kehandalan pekerjaan. Sedangkan Benevolence, didasarkan pada besarnya kepercayaan kemitraan yang memiliki tujuan dan motivasi yang menjadi kelebihan untuk organisasi lain pada saat kondisi yang baru muncul, yaitu kondisi dimana komitmen tidak terbentuk. (Adisetiawan, 2013)

Melihat begitu pentingnya faktor kepercayaan pada bisnis perbankan, maka sudah semestinyalah bank menjadikan faktor kepercayaan sebagai prioritas utama yang harus di perhatikan dalam menjaga nasabahnya. Menurut Elrado, Kumadji, dan Yulianto (2014) kepercayaan dapat ditingkatkan melalui kualitas pelayanan yang diberikan. Sejalan dengan Elrado, Kumadji, dan Yulianto (2014) hal yang sama juga dikemukakan Nurhadi dan Azis (2018) dalam penelitiannya yang mengungkapkan bahwa semakin tinggi tingkat kualitas pelayanan yang diberikan maka semakin tinggi pula kepercayaan yang diterima oleh konsumen. Selain itu Pramana dan Rastini (2016) menyimpulkan bahwa kualitas pelayanan dari sebuah jasa merupakan sebuah faktor yang penting dalam mencapai kepercayaan dari nasabahnya.

Kualitas pelayanan merupakan salah satu faktor penentu keberhasilan yang mempengaruhi daya saing organisasi. Sebuah bank dapat membedakan dirinya dari pesaing dengan menyediakan layanan berkualitas tinggi.Bank yang ingin berkembang harus dapat memberikan kualitas pelayanan yang baik dan memberikan rasa aman kepada nasabah, karena hal itu merupakan salah satu faktor penentu keberhasilan dari suatu bank. Dengan memberikan kualitas pelayanan yang baik dan rasa aman kepada nasabah, tidak hanya meningkatkan kepercayaan bagi nasabah, namun juga akan menimbulkan suatu kepuasan bagi nasabah. Hal ini dikemukakan Pratiwi dan Seminari (2015) yang mengungkapkan bahwa kualitas pelayanan 
berpengaruh terhadap kepuasan. Penelitian ini juga didukung Guspul (2014) dimana dari hasil penelitiannya kualitas pelayanan memiliki pengaruh yang lebih dominan dibandingkan dengan variabel lainnya.

Kepuasan nasabah merupakan inti dari pencapaian profit dalam jangka panjang. Kepuasan nasabah didasarkan pada upaya meniadakan atau setidaknya mengurangi kesenjangan. Yulianto (2015) menyatakan bahwa kepuasan nasabah didefinisikan sebagai evaluasi purnabeli, di mana persepsi terhadap kinerja alternanif atau produk/jasa yang digunakan melebihi atau memenuhi harapan. Nasabah yang telah mencapai kepuasan sangat memungkinkan sekali untuk memberitahukan kepada teman, rekan maupun orang lain akan pengalaman yang mereka dapatkan tentang produk atau jasa perusahaan. Dengan terciptanya tingkat kepuasan nasabah yang optimal maka akan mendorong terciptanya loyalitas di benak nasabah yang sudah merasa puas. Sesuai dengan permasalahan yang diajukan dalam penelitian, maka tujuan dari peneltian ini yaitu menganalisis pengaruh kualitas pelayanan melalui kepercayaan terhadap kepuasan nasabah. Kepercayaan adalah keyakinan bahwa seseorang akan menemukan apa yang diinginkan pada mitra pertukaran. Kepercayaan melibatkan kesediaan seseorang untuk bertingkah laku tertentu karena keyakinan bahwa mitranya akan memberikan apa yang diharapkan dan suatu harapan yang dimiliki seseorang bahwa kata janji atau pernyataan orang lain dapat dipercaya (Barnes, 2009).

Menurut Kotler (2008) kepercayaan adalah gagasan deskriptif yang dianut oleh seseorang tentang sesuatu".Kepercayaan mungkin didasarkan pada pengetahuan dan opini.Kepercayaan merupakan tingkat kepastian konsumen ketika pemikirannya diperjelas dengan mengingat yang berulang-ulang dari pelaku pasar dan teman-temanya. Kepercayaan bisa mendorong maksud untuk membeli atau menggunakan produk dengan cara menghilangkan keraguan. Menurut Yee dan Faziharudean (2010) menyatakan bahwa indikator kepercayaan terdiri dari 3 (tiga) komponen yaitu (1) Integritas (Integrity), merupakan persepsi konsumen bahwa perusahaan mengikuti prinsip-prinsip yang dapat diterima seperti menepati janji, berperilaku sesuai etika dan jujur; (2) kebaikan (Benevolence), yang didasarkan pada besarnya kepercayaan kemitraan yang memiliki tujuan dan motivasi yang menjadi kelebihan untuk organisasi lain pada saat kondisi yang baru muncul, yaitu kondisi dimana komitmen tidak terbentuk; dan (3) kompetensi (Competence), kompetensi merupakan kemampuan untuk memecahkan permasalahan yang dihadapi oleh konsumen dan memenuhi segala keperluannya. (Adisetiawan dan Asmas, 2012)

Menurut Siswoyo (2011) kualitas merupakan suatu kondisi dinamis yang berhubungan dengan produk, jasa, manusia, proses dan lingkungan yang memenuhi atau melebihi harapan. Menurut American Society for Quality Control dalam Kotler (2008) kualitas jasa adalah keseluruhan ciri serta sifat dari suatu produk atau pelayanan yang berpengaruh pada kemampuannya untuk memuaskan kebutuhan yang dinyatakan atau yang tersirat. Kualitas pelayanan telah dikonseptualisasikan sebagai perbedaan antara harapan pelanggan mengenai pelayanan yang akan diterima dan persepsi jasa yang diterima (Akbar dan Parves, 2009). Kualitas pelayanan dapat diidentifikasi melalui penelitian yang dilakukan yang dikenal sebagai SERVQUAL yaitu: 1) Bukti Fisik (Tangibles); 2) Keandalan (Reliability); 3) Daya Tanggap (Responsiveness); 4) Jaminan (Assurance) dan; 5) Empati (Empathy). Berdasarkan penelitian yang dilakukan Jabnoun dan Khalifa (2005) dari lima dimensi kualitas pelayanan diatas dengan analisis faktor menghasilkan empat dimensi: Personal Skills (Keterampilan perseorangan), Reliability (Keandalan), Value (Nilai), dan Image (Citra). Empat dimensi inilah yang digunakan dalam mengukur kualitas pelayanan dalam penelitian ini.

Saat ini kepuasan menjadi fokus perhatian oleh hampir semua pihak baik pemerintah, pelaku bisnis, dan konsumen. Hal ini disebabkan semakin baiknya pemahaman atas konsep kepuasan sebagai strategi untuk memenangkan persaingan di dunia bisnis.Secara sederhana kepuasan diartikan sebagai 'upaya pemenuhan sesuatu atau membuat sesuatu memadai (Tjiptono, 2007). Tjiptono (2007) mengungkapkan bahwa kepuasan pelanggan adalah situasi kognitif pembeli yang berkenaan dengan kesepadanan atau ketidaksepadanan antara hasil yang didapatkan dengan pengorbanan yang dilakukan. Akbar dan Parves (2009) menyatakan bahwa kepuasan adalah evaluasi pelanggan tentang produk atau pelayanan, apakah produk atau layanan itu telah memenuhi kebutuhan dan harapan mereka. Kepuasan pelanggan memainkan peran yang penting karena terdapat perbedaan yang besar dalam loyalitas, antara pelanggan yang sekedar puas dan yang benar- benar puas (Lovelock dan Wright, 2007). Menurut Simamora (2007) adapun indikator yang dapat digunakan dalam mengukur kepuasan adalah: (1) pilihan tepat yaitu perasaan pelanggan dalam 
memilih perusahaan sebagai mitranya adalah pilihan yang tepat; (2) kesesuaian harapan yaitu perasaan pelanggan akan kemampuan perusahaan untuk memenuhi harapannya; dan (3) kepuasan fasilitas merupakan perasaan puas pelanggan terhadap kelengkapan fasilitas yang disediakan perusahaan. Berdasarkan tujuan penelitian, kajian pustaka, penelitian terdahulu dan hubungan antar variabel maka kerangka analisis dalam penelitian ini disajikan dalam bentuk Gambar 1. Dimana variabel kualitas pelayanan merupakan variabel independent, variabel kepuasan sebagai variabel dependent dan variabel kepercayaan sebagai variabel intervening, atau variabel yang memediasi antara variabel independent dengan variabel dependent.

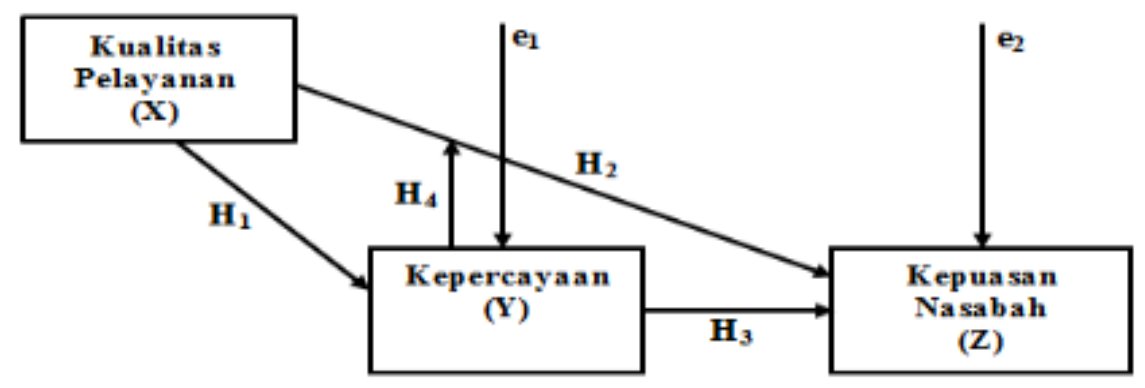

\section{Gambar 1 Kerangka Berpikir}

\section{Hipotesis}

Hipotesis dalam penelitian adalah diduga kualitas pelayanan melalui kepercayaan berpengaruh terhadap kepuasan nasabah.

\section{METODE PENELITIAN}

Unit analisis penelitian ini adalah nasabah BRI Kcp unit Kuamang Kuning yang berjumlah 9.359 nasabah hingga tahun 2015. Ukuran atau jumlah sampel dalam penelitian ini ditentukan berdasarkan teori yang dikembangkan oleh Slovin.dengan rumus: $n=\frac{N}{1+N e^{2}}$. Berdasarkan rumus penentuan jumlah sampel dari Slovin di atas didapat jumlah sampelnya (n) sebanyak 383,61 di bulatkan menjadi 384 dengan nilai e = $5 \%$.

Pendekatan penelitian yang digunakan dalam penelitian ini adalah pendekatan kuantitatif dengan menggunakan analisis jalur (Path Analysis). Analisis ini merupakan pengembangan dari persamaan regresi, yang merupakan salah satu pilihan dalam rangka mempelajari ketergantungan sejumlah variabel didalam model.Analisis ini merupakan metode yang baik untuk menerangkan apabila terdapat seperangkat data yang besar untuk dianalisis dan mencari hubungan kausal (Ghozali, 2012). Setelah dianalisis kemudian dilanjutkan dengan uji analisis determinasi ( $R$ Square), pengujian hipotesis secara parsial (uji t) toleransi error 5 persen, serta pengujian hipotesis mediasidengan uji Sobel (Sobel test).Namun sebelumnya terlebih dahulu di uji instrumen penelitian (kuesioner) dengan uji validitas dan realibilitas, serta melakukan uji normalitas.

\section{HASIL DAN PEMBAHASAN}

\section{Deskripsi Data Kualitas Pelayanan (X)}

Hasil deskriptif diketahuibahwa nasabahcukup setuju jika kualitas pelayanan yang diberikan oleh BRI Kcp Unit Kuamang Kuning Kabupaten Bungo cukup baik dalam memberikan pelayanan kepada nasabah.Artinya karyawan mampu memberikan rasa aman dan nyaman kepada nasabah, dapat memahami kebutuhan nasabah, adanya kesesuaian layanan dengan yang dijanjikan, memiliki fasilitas yang baik serta memiliki citra yang baik dimata nasabah. 


\section{Deskripsi Data Variabel Kepercayaan (Y)}

Hasil deskriptifdiketahui bahwa nasabah setuju jika nasabah menggunakan jasa Bank BRI berdasarkan atas kepercayaan nasabah terhadap bank tersebut.BRI memiliki reputasi yang baik, BRI dapat memberikan pelayanan sesuai dengan prosedur yang ditentukan, BRI selalu memberikan yang terbaik bagi nasabahnya, BRI selalu memberikan pelayanan semaksimal mungkin demi kepuasan nasabahnya, serta BRI merupakan perusahaan yang kompeten dibidangnya.

\section{Deskripsi Data Variabel Kepuasan (Z).}

Hasil deskriptif diketahuibahwa nasabahtelah merasa puas menjadi nasabah BRI selama ini.Hal ini dapat ditunjukan denganadanya perasaan telah memilih bank yang tepat sebagai mitra, adanya kesesuaian pelayanan yang diberikan dengan harapan, serta adanya rasa puas terhadap kelengkapan fasilitas yang diberikan oleh perusahaan.

\section{Hasil Uji Normalitas}

Pada dasarnya uji normalitas dengan grafik dapat menyesatkan apabila tidak hati-hati secara visual kelihatan normal, padahal secara statistic bisa sebaliknya.Dari uji normalitas yang dilakukan secara statistik, diperoleh nilai Asymp. Sig. 2-tailed lebih besar dari 0,05 $(0,802>0,05)$ sehingga dapat disimpulkan bahwa data dalam penelitian ini berdistribusi normal.

\section{Analisis Jalur (Path Analisis)}

Untuk menjawab tujuan-tujuan dalam penelitian ini, struktur utama dalam model penelitian di pecah menjadi dua sub struktur. Dimana untuk menjawab tujuan 1 dengan sub struktur pertama, untuk menjawab tujuan 2 dan 3 dengan menggunakan sub struktur kedua, dan untuk menjawab tujuan 4 nilai yang diambil merupakan nilai output sub struktur pertama dan keduauntuk melihat pengaruh langsung dan tidak langsung. Berikut ini merupakan output SPSS dari dua struktur yang dirangkum pada tabel berikut.

Tabel 1

Output SPSS Dua Sub Struktur.

\begin{tabular}{|c|c|c|c|c|c|}
\hline \multirow{2}{*}{ Model } & \multicolumn{2}{|c|}{ Unstandardized Coefficients } & \multirow{2}{*}{$\begin{array}{c}\text { Standardized Coefficients } \\
\text { Beta }\end{array}$} & \multirow{2}{*}{$\mathrm{t}$} & \multirow{2}{*}{ Sig. } \\
\hline & $\mathrm{B}$ & Std. Error & & & \\
\hline $\mathrm{X}-\mathrm{Y}$ & 0.389 & 0.030 & 0.637 & 12.938 & 0.000 \\
\hline $\mathrm{X}-\mathrm{Z}$ & 0.121 & 0.021 & 0.340 & 5.734 & 0.000 \\
\hline $\mathrm{Y}-\mathrm{Z}$ & 0.252 & 0.034 & 0.433 & 7.311 & 0.000 \\
\hline
\end{tabular}

Sumber: Data olahan

Hasil output diatas di masukkan ke dalam gambar persamaan struktural sebagai berikut:

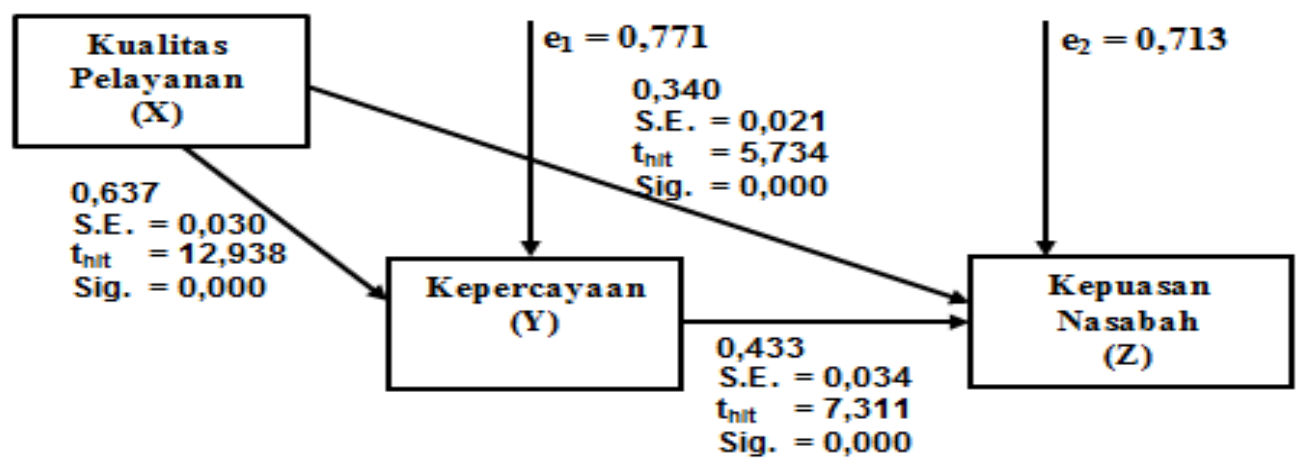

Gambar 2

Hasil Analisis Jalur 
Untuk melihat seberapa besar sumbangankualitas pelayanan (X) dan kepercayaan (Y) terhadap kepuasan (Z) dapat dilihat dari nilai koefisien determinasi $\mathrm{R}^{2}$ seperti yang terlihat pada Tabel 2 berikut:

Tabel 2

Model Summary

\begin{tabular}{|l|r|r|r|r|}
\hline Model & R & R Square & Adjusted R Square & Std. Error of the Estimate \\
\hline 1 & $.701^{\mathrm{a}}$ & .491 & .487 & 1.5069 \\
\hline
\end{tabular}

Sumber: Data olahan

Nilai R sebesar 0,701 menunjukan korelasi ganda (kualitas pelayanan dan kepercayaan) dengan kepuasan nasabah. Dengan mempertimbangkan variasi nilai $\mathrm{R}$ Square sebesar 0,491 yang menunjukan besarnya sumbangan atau kontribusi variabel kualitas pelayanan dan kepercayaan mampu menjelaskan variabel kepuasan sebesar 49,1 persen dan sisanya 50,9 persen dipengaruhi oleh faktor lain yang tidak diungkap dalam model ini.

\section{Uji Hipotesis}

\section{1) Pengaruh Kualitas Pelayanan Terhadap Kepercayaan.}

Dari hasil output SPSS sperti yang tampak pada Tabel 1yang dilakukan diperoleh angka nilai t hitung variabel X terhadap Y sebesar 12.938, dengan tingkat signifikansi sebesar 0,000, dikarenakan angka taraf signifikansi lebih $<0.05(0.000<0.05)$ maka dapat disimpulkan bahwa kualitas pelayanan berpengaruh terhadap kepuasan nasabah. Berdasarkan dari penjelasan tersebut oleh karena itu $\mathrm{H}_{0}$ ditolak dan $\mathrm{H}_{1}$ diterima, artinya kualitas pelayanan berpengaruh terhadap kepuasan nasabah. Hasil penelitian ini menunjukan hasil yang sama dengan penelitian yang dilakukan Elrado, Kumadji, dan Yulianto (2014) yang menunjukan bahwa kualitas pelayanan memiliki pengaruh terhadap kepercayaan. Sejalan dengan Elrado, Kumadji, dan Yulianto (2014), hal yang sama juga dikemukakan Nurhadi dan Azis (2018) dalam penelitiannya yang mengungkapkan bahwa semakin tinggi tingkat kualitas pelayanan yang diberikan maka semakin tinggi pula kepercayaan yang diterima oleh konsumen. Selain itu Pramana, dan Rastini (2016) menyimpulkan bahwa kualitas pelayanan dari sebuah jasa merupakan sebuah faktor yang penting dalam mencapai kepercayaan dari nasabahnya.

\section{2) Pengaruh Kualitas Pelayanan Terhadap Kepuasan}

Dari hasil output SPSS sperti yang tampak pada Tabel 1 yang dilakukan diperoleh angka nilai $\mathrm{t}$ hitung variabel $X$ terhadap Ztersebesar 5.734, dengan tingkat signifikansi sebesar 0,000, dikarenakan angka taraf signifikansi lebih $<0.05(0.000<0.05)$ maka dapat disimpulkan bahwa kualitas pelayanan berpengaruh terhadap kepuasan nasabah. Berdasarkan dari penjelasan tersebut oleh karena itu $\mathrm{H}_{0}$ ditolak dan $\mathrm{H}_{1}$ diterima, artinya kualitas pelayanan berpengaruh terhadap kepuasan nasabah. Hasil penelitian ini menunjukan hasil yang sama dengan penelitian yang dilakukan Pratiwi dan Seminari (2015) menemukan bahwa kualitas pelayanan berpengaruh terhadap kepuasan. Penelitian ini juga didukung Guspul (2014) dimana dari hasil penelitiannya kualitas pelayanan memiliki pengaruh yang lebih dominan dibandingkan dengan variabel lainnya. Kualitas pelayanan merupakan salah satu faktor penentu keberhasilan yang mempengaruhi daya saing organisasi. Sebuah bank dapat membedakan dirinya dari pesaing dengan menyediakan layanan berkualitas tinggi. Bank yang ingin berkembang harus dapat memberikan kualitas pelayanan yang baik dan memberikan rasa aman kepada nasabah, karena hal itu merupakan salah satu faktor penentu keberhasilan dari suatu bank. Dengan memberikan kualitas pelayanan yang baik dan rasa aman kepada nasabah, maka akan menimbulkan suatu kepuasan bagi nasabah dan sebaliknya. Demikian juga yang terjadi pada Bank Rakyat Indonesia (BRI) Cabang Kuamang Kuning Kabupaten Bungo sejak beroperasinya 21 tahun yang lalu, tepatnya pada tahun 1994 Bank ini selalu melakukan pembenahan dalam upaya memperbaiki pelayanan yang diberikan kepada nasabah, sebagai upaya memberikan kepuasan kepada nasabah untuk menggunakan jasa yang ditawarkan.

\section{3) Pengaruh Kepercayaan Terhadap Kepuasan}

Hasil pada Tabel 1 yang dilakukan diperoleh angka nilai t hitung variabel $\mathrm{Y}$ terhadap $\mathrm{Z}$ sebesar 7.311, dengan tingkat signifikansi sebesar 0,000, dikarenakan angka taraf signifikansi lebih $<0.05(0.000<$ 
0.05) maka dapat disimpulkan bahwa kepercayaan berpengaruh terhadap kepuasan nasabah. Berdasarkan dari penjelasan tersebut oleh karena itu $\mathrm{H}_{0}$ ditolak dan $\mathrm{H}_{1}$ diterima, artinya kepercayaan berpengaruh terhadap kepuasan nasabah. Hasil penelitian ini menunjukan hasil yang sama dengan penelitian yang dilakukan Pratiwi dan Seminari (2015), Guspul (2014), Yulianto (2015) dimana hasil penelitian menyatakan bahwa kepercayaan memiliki pengaruh yang positif dan signifikan terhadap kepuasan. Bisnis perbankan pada dasarnya berdasarkan pada prinsip kepercayaan. Faktor kepercayaan masyarakat merupakan suatu faktor yang amat penting, karena tanpa kepercayaan maka masyarakat tidak akan menabung dananya di bank, untuk itu bank harus mampu menjaga kepercayaan masyarakat tersebut. Setiap nasabah selalu mengharapkan keuntungan dari dana yang disimpan pada bank dan di sisi lain nasabah tersebut tidak mau kehilangan dananya pada bank, nasabah sangat mengharapkan penuh atas setiap penarikan uangnya yang ditabung pada bank. Oleh karena itu nasabah akan memilih bank yang benar-benar dapat dipercaya sebagai tempat menyimpan dana mereka, dan kepercayaan terhadap bank menjadi sangat penting. Dalam hubungan dengan peningkatan jumlah nasabah maka bank harus dapat menciptakan kepercayaan masyarakat terhadap bank sehingga masyarakat akan merasa aman menyimpan dana mereka pada bank (Simorangkir, 2007).

\section{4) PengaruhKualitas Pelayanan Melalui Kepercayaan Terhadap Kepuasan Nasabah.}

Untuk mengetahui apakah variabel kepuasan mampu memediasi variabel kepercayaan terhadap loyalitas adapun langkahnya sebagai berikut.

Pengaruh langsung kualitas pelayanan terhadap kepuasan

$$
\begin{aligned}
& =\text { Pyx (p1) } \\
& =0,340
\end{aligned}
$$

Pengaruh tidak langsung kualitas pelayanan terhadap kepuasan

$=$ Pyx $(\mathrm{p} 2) \times$ Pzy $(\mathrm{p} 3)$

$=0,637 \times 0,433=0,275821$

Total pengaruh (kualitas pelayanan terhadap kepuasan)

$=\mathrm{p} 1+(\mathrm{p} 2 \times \mathrm{p} 3)$

$=0,340+0,275821=0,615821$.

Hasil analisis jalur menunjukan bahwa kualitas pelayanan dapat berpengaruh langsung terhadap kepuasan nasabah dan dapat juga berpengaruh tidak langsung yaitu dari kualitas pelayanan ke kepercayaan (sebagai variabel intervening) lalu ke kepuasan. Untuk mengetahui pengaruh mediasi ditunjukan oleh perkalian koefisien (p2 x p3) sebesar 0,615821 signifikan atau tidak, diuji dengan Sobel test sebagai berikut: Hitung standar error dari koefisien indirect effect (Sp2p3)

$S p 2 p 3=\sqrt{p 3^{2} S p 2^{2}+p 2^{2} S p 3^{2}+S p 2^{2} S p 3^{2}}$

Sp2p3 $=\sqrt{(0,433)^{2}(0,030)^{2}+(0,637)^{2}(0,034)^{2}+(0,030)^{2}(0,034)^{2}}$

$S p 2 p 3=\sqrt{(0,187489.0,0009)+(0,405769.0,001156)+(0,0009.0,001156)}$

Sp2p3 $=\sqrt{0,0001687401+0,000469068964+0,0000010404}$

Sp2p3 $=\sqrt{0,000638849464}=0,025$

Berdasarkan hasil Sp2p3 ini kita dapat menghitung nilai t statistik pengaruh mediasi dengan rumus sebagai berikut:

$\mathrm{t}=\frac{p 2 p 3}{S p 2 p 3}=\frac{0,615821}{0,025}=24,633$

Oleh karena nilai t hitung $=24,633$ lebih besar dari nilai t tabel dengan tingkat signifikan 0,05 yaitu 1,652, maka dapat disimpulkan bahwa koefisien mediasi 0,615821 signifikan yang berarti ada pengaruh mediasi.

\section{SIMPULAN} berikut:

Berdasarkan hasil penelitian dan pembahasan dalam tesis ini, maka dapat disimpulkan sebagai

a. Berdasarkan hasil perhitungan dan analisis, diketahui bahwa kualitas layanan memiliki pengaruh terhadap kepercayaan nasabah pada BRI Kcp Unit Kuamang Kuning Kabupaten. Hal ini menjelaskan 
jika bank ingin meningkatkan kepercayaan nasabah melalui kualitas pelayanan, maka bank dapat meningkatkan

b. Berdasarkan hasil perhitungan dan analisis, diketahui bahwa kualitas layanan memiliki pengaruh terhadap kepuasan nasabah pada BRI Kcp Unit Kuamang Kuning Kabupaten.

c. Berdasarkan hasil perhitungan dan analisis, diketahui bahwa kepercayaan memiliki pengaruh terhadap kepuasan nasabah pada BRI Kcp Unit Kuamang.

d. Kepercayaan mampu memediasikualitas pelayanan terhadap kepuasan nasabah pada BRI Kcp Unit Kuamang Kuning Kabupaten.

\section{DAFTAR PUSTAKA}

Adisetiawan, R., 2013, Kajian Persepsi Pemilik Usaha Kecil dan Menengah (UKM) terhadap Laporan Keuangan, Jurnal Ilmiah Universitas Batanghari Jambi, 13(4), 162-173

Adisetiawan, R., dan Denny Asmas, 2012, Hubungan EVA dan MVA sebagai alat Pengukur Kinerja Perusahaan Serta Pengaruhnya Terhadap Harga Saham, Jurnal Ilmiah Universitas Batanghari Jambi, 12(1), 12-18

Akbar, M.M., and Parvez, N., 2009. Impact of Services Quality, Trust, and Customer Satisfaction on Customer Loyalty, ABAC Journal, 29(1), 24-38.

Barnes, 2009. Elemen Kepercayaan. Diambil 16 Februari 2016, dari situs World Wide Web:(http://barnes.blogspot.com/2011/04/elemen-kepercayaan.html).

Elrado H, M., Kumadji, S., dan Yulianto, E., 2014. Pengaruh Kualitas Pelayanan Terhadap Kepuasan, Kepercayaan dan Loyalitas (Survei pada Pelanggan yang Menginap di Jambuluwuk Batu Resort Kota Batu). Jurnal Administrasi Bisnis (JAB), 15(2).

Ghozali, I., 2012. Aplikasi Analisis Multivariate Dengan Program SPSS. Semarang: Penerbit Undip.

Guspul, A., 2014. Pengaruh Kualitas Pelayanan dan Kepercayaan Terhadap Kepuasan Nasabah (Studi Kasus Pada Nasabah Kospin Jasa Cabang Wonosobo). Jurnal PPKM UNSIQ I.

Jabnoun, N and Khalifa, A., 2005. A Customized Measure Of Service Quality In The UAE. Managing Service Quality, 15(4).

Jasfar, F., 2000. Kualitas Jasa dan Hubungannya Dengan Loyalitas Serta Komitmen : Studi Pada Pelanggan Salon Kecantikan. Jurnal Siasat Bisnis, 7(1).

Kotler, P., 2008. Manajemen Pemasaran. Jakarta: PT Indeks.

Lovelock, C.H dan Wright, L.K., 2007. Manajemen Pemasaran Jasa. Edisi Bahasa Indonesia. Jakarta: PT Indeks.

Nurhadi dan Azis, A., 2018. Pengaruh Kualitas Pelayanan Terhadap Kepercayaan dan Kesetiaan Konsumen.Jurnal Economia, 14(1).

Pramana, I.G.Y., dan Rastini, N.M., 2016. Pengaruh Kualitas Pelayanan Terhadap Kepercayaan Nasabah dan Loyalitas Nasabah Bank Mandiri Cabang Veteran Denpasar Bali. E-Jurnal Manajemen Unud, $5(1)$.

Pratiwi, N.P.L dan Seminari, N.K., 2015. Pengaruh Kualitas Pelayanan, Kepercayaan dan Nilai Nasabah Terhadap Kepuasan Nasabah. E-Jurnal Manajemen Unud, 4(5).

Simamora, E.S., 2007. Analisis Faktor-Faktor YangMembangun Kepuasan Nasabah Untuk Meningkatkan Loyalitas Pelanggan. (Studi Empiris Nasabah PT. Bank Tabungan Negara Cabang Semarang). Tesis, Universitas Diponegoro Semarang.

Simorangkir, O. P., 2007. Pengantar Lembaga Keuangan Bank dan Non Bank. Bogor: Ghalia Indomnesia.

Siswoyo, E., 2011. Analisis Pengaruh Kualitas Pelayanan, Kepercayaan dan Kepuasan Nasabah Terhadap Loyalitas Nasabah Pada PT. Bank Jateng Pemuda Semarang.

Tjiptono, F., 2007. Manajemen Jasa. Yogyakarta: Andi Offset.

Yee, B.H and Faziharudean., 2010. Factors Affecting Customer Loyalty of Using Internet Banking in Malaysia. Journal of Electronic Banking Sytems.

Yulianto, T., 2015. Pengaruh Kualitas Pelayanan ATM dan Kepercayaan Terhadap Kepuasan Nasabah (Studi Kasus pada Nasabah Bank BRI). Tesis Universitas Muhammadiyah Surakarta. 